\title{
The timing of peak high-grade metamorphism in central-eastern New England
}

\author{
J. Dykstra Eusden Jr.* \\ and \\ Barbara Barreiro \\ Department of Earth Sciences, Dartmouth College, Hanover, New Hampshire 03755 U.S.A.
}

Date Received June 28, 1988

Date Accepted March 1, 1989

\begin{abstract}
Monazite and sphene, separated from sillimanite-grade schists, gneisses and two-mica granites in the Central Maine Terrane and Merrimack Trough, have been dated using the U-Pb system. The ages constrain the timing of peak high-grade metamorphism and plutonism in northern New England. In the Central Maine Terrane metamorphic ages are Acadian (early Devonian); in the Merrimack Trough, across the Campbell Hill-Nonesuch River-Norumbega fault zone, the age of metamorphism is Alleghenian(?)(Permian). The granite ages outline a distinct pulse of Devonian magmatism, characteristic of the Central Maine Terrane.

The high-grade terrane of this part of the Appalachian Orogen is composite. It is made up of crustal blocks that experienced discrete pulses of high-grade metamorphism beginning perhaps as long ago as the pre-Middle Ordovician and extending into the Permian. Ages of peak metamorphism support the hypothesis that the Central Maine and Merrimack terranes had different tectono-metamorphic histories and are coincidentally juxtaposed at the same metamorphic grade.

The Campbell Hill-Nonesuch River-Norumbega fault zone has had an active and complex history, beginning approximately $360 \mathrm{Ma}$ and lasting at least to $250 \mathrm{Ma}$. This boundary is a likely candidate for the westem Alleghenian (Variscan) Front in New England. The final juxtaposition of the Central Maine and Merrimack terranes may have occurred during the Mesozoic along extensional, terrane-bounding faults, possibly the reactivated Acadian compressional and/or Alleghenian transpressional structures.
\end{abstract}

L'application de la systématique U-Pb a permis la datation de la monazite et du sphène extraits de schistes métamorphisés au grade de la sillimanite, de gneiss et de granites à deux micas provenant de la Lanière de Central Maine et de la Fosse de Merrimack. Les âges ainsi obtenus imposent des contraintes précises sur l'époque du paroxysme métamorphique et du plutonisme en Nouvelle-Angleterre septentrionale. Dans la Lanière de Central Maine, le métamorphisme est d'âge acadien (éodévonien). Dans la Fosse de Merrimack, d'un côté à l'autre de la zone de failles de Campbell Hill-Nonesuch RiverNorumbega, le métamorphisme date de l'Alléghanien(?)(Permien). Les âges des granites mettent en évidence un épisode distinct de magmatisme dévonien qui caractérise la Lanière de Central Maine.

Dans cette portion de l'Orogène appalachien, la lanière présentant un haut degré de métamorphisme est composite. Elle comprend des blocs crustaux ayant subi des épisodes distincts de métamorphisme de haut degré qui débutent possiblement à l'Ordovicien moyen pour s'étaler jusqu'au Permien. Les âges du paroxysme métamorphique confortent l'hypothèse voulant que les lanières de Central Maine et de Merrimack aient eu des histoires tectono-métamorphiques différentes et que leur juxtaposition à un même grade métamorphique ne soit que coüncidence.

L'histoire de la zone de failles de Campbell Hill-Nonesuch River-Norumbega est active, complexe et s'échelonne d'environ $360 \mathrm{Ma}$ jusqu'à au moins $250 \mathrm{Ma}$. Cette frontière forme un candidat plausible pour le Front alléghanien (varisque) occidental en Nouvelle-angleterre. La juxtaposition finale des lanières de Central Maine et de Merrimack s'effectua peut-être au Mésozoïque le long de failles en extension bordant les lanières, possiblement par réactivation des accidents compressifs acadiens et/ou des structures transpressives alléghaniennes.

[Traduit par le joumal]

\section{INTRODUCTION}

We present $\mathrm{U}-\mathrm{Pb}$ ages for monazite and sphene from schists and granites in what are thought to be two juxtaposed geologic terranes, the Central Maine Terrane (Zen et al., 1986) and the Merrimack Traugh. The Merrimack Trough includes both the basement (Massabesic Gneiss Complex) and the cover sequence (Merrimack Group). The term Central Maine Terrane is used

*Present address: Department of Geology, Bates College, Lewiston, Maine, 04240 U.S.A. 
instead of Kearsarge-Central Maine Synclinorium, as defined by Lyons et al. (1982), to provide distinction between the Kearsarge-Central Maine Synclinorium proper, now recognized as only one of several synclinorial fold structures in the Central Maine Terrane, and the entire Siluro-Devonian basin itself.

Although the Central Maine Terrane and Merrimack Trough are thought to have had markedly different tectono-thermal histories (Lyons et al., 1982; Gaudette et al., 1984; Bothner et al., 1984), they are juxtaposed at the same metamorphic grade. A knowledge of the time of peak high-grade metamorphism can test the composite terrane model put forth for this region. It is crucial to tectonic models to understand the precise timing of metamorphic events relative to regional deformation and the intrusion of syn- and post-tectonic plutons which may control or drive metamorphism. Constraints on the timing of metamorphism become even more critical when dealing with discrete terranes made up of somewhat lithologically similiar rocks at the same grade of metamorphism, as is the case for the Merrimack Trough and Central Maine Terrane. Fieldwork must be complemented by geochronology to establish the tectonic history.

\section{REGIONAL GEOLOGY}

Through the past decade, a progressively convincing data base has emerged suggesting that the coastal geology of the northern New England Appalachians is a composite of distinct lithotectonic terranes (Lyons et al., 1982; Gaudette et al., 1984; Bothner etal., 1984;Zen etal., 1986; Hussey, 1985; Osberg etal., 198.5). The major terranes in this region are shown in Figure 1. The Central Maine Terrane is bounded on the southeast by the Campbell Hill-Nonesuch River-Norumbega fault zone. Southeast of this terrane boundary lies the Coastal Lithotectonic Block of Maine, and the Merrimack Trough of southwestern Maine and southeastem New Hampshire. Along the New Hampshire coast

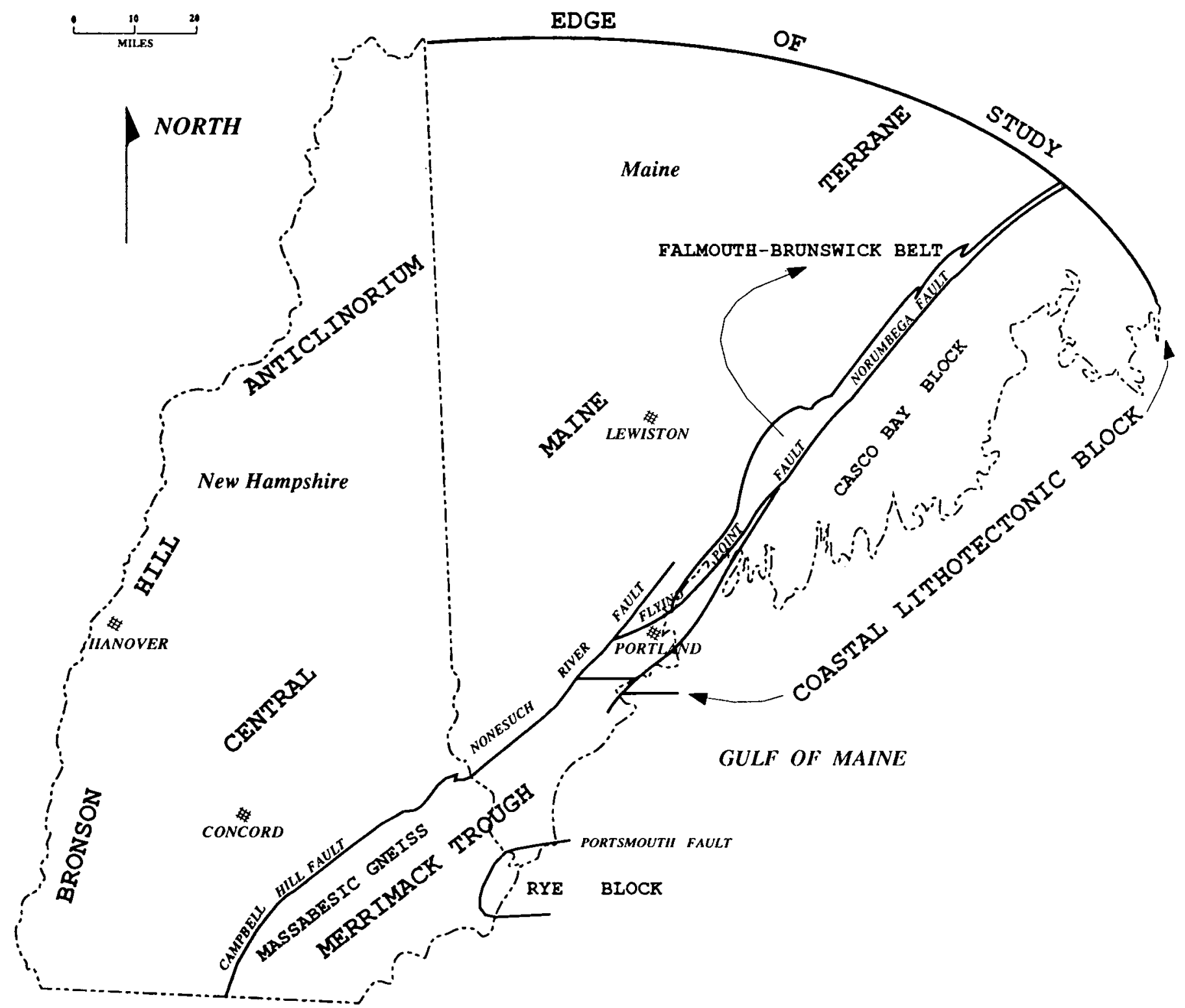

Fig. 1. Terranes of central and southeastem New Hampshire and southwestem Maine. Modified from Lyons et al. (1986), Osberg et al. (1985), and Hussey (1985). 
and juxtaposed against the Merrimack Trough along the Portsmouth fault is the "Rye Block" (note: all the names that are in quotes are informally used here). Within the Coastal Lithotectonic Block are the Falmouth-Brunswick Belt (Hussey, 1985) and "Casco Bay Block" separated by the Flying Point fault. The Flying Point fault connects the Nonesuch River and Norumbega faults providing the link in a master fault system that extends from Massachusetts to New Brunswick (Fig. 1). The "Casco Bay Block" includes Hussey's (1985) Casco Bay Group, South Portland-Harpswell Belt, and East Harpswell-Merrymeeting Bay Belt. These terranes have intervening faults but have been grouped together here for simplicity. The Coastal Lithotectonic Block is separated from the Merrimack Trough by an east-west trending thrust fault in southwestern Maine (Hussey, 1985; Osberg et al., 1985) (Fig. 1).

\section{CENTRAL MAINE TERRANE}

The Central Maine Terrane is composed of Late Ordovician to Early Devonian metasedimentary rocks (predominantly turbidites) that are multiply deformed and complexly metamorphosed. In New Hampshire, the metasedimentary rocks are Siluro-Devonian in age (Silurian Rangeley, Perry Mountain, Smalls Falls, and Madrid formations and Devonian Littleton Formation) (Lyons et al., 1986). In Maine the deeper levels of the section, the Late Ordovician or Early Silurian Vassalboro Formation, are exposed (Osberg et al., 1985). These metasedimentary rocks are part of a large basin, extending from New Brunswick to Connecticut, and their source in Late Ordovician through Silurian time was centered over the Bronson Hill Anticlinorium. In the Early Devonian, the source switched to the east-northeast (Hatch et al., 1983; Hanson and Sauchuk, 1986; Hall et al., 1976).

The metamorphic rocks are intruded by thin sheet-like (Hodge et al., 1982; Nielson et al., 1976) granitic rocks of the New Hampshire Plutonic Series (Lyons et al., 1986). The New Hampshire Plutonic Series has three broad categories of granitoid rocks: (1) large, Early Devonian, syn-tectonic plutons (e.g., Bethlehem Gneiss, Kinsman Quartz Monzonite, Spaulding and Winnipesaukee Quartz Diorites, and Mooselookmeguntic Pluton); (2) smaller, Middle to Late Devonian, syn- and post-tectonic bodies of predominantly two-mica granite (e.g., Concord Granite); and (3) Carboniferous, predominantly post-tectonic, twomica granites (e.g., Sebago Pluton and Effingham Pluton) (Fig. 2) (Lyons et al., 1982; Lyons et al., 1986; Osberg et al., 1985).

The complex deformation of the Central Maine Terrane has historically been considered Acadian in age (Lyons et al., 1982). Recent radiometric work by Hubacher and Lux (1987) has confirmed the Acadian age of deformation in Maine. At least four episodes of regional deformation have been recognized. In the Central Maine Terrane of New Hampshire a regional east and west verging nappe-stage folding event was followed by thrusting and then by three episodes of folding. Much of the section is inverted as a consequence, and most of the major fold structures face downward or are at least compound refolded structures (Eusden et al., 1987; Robinson, 1987; Thompson et al., 1987).

Though the style and sequence of Acadian regional deformation in Massachusetts and New Hampshire is essentially the same and attributed to regional strain, the deformation in parts of Maine is interpreted as magma-generated and different in style and sequence (Moench and Zartman, 1976). The change in structural style may be a reflection of a transition from higher (Maine) to lower (New Hampshire and Massachusetts) crustal levels in the Central Maine Terrane (Moench et al., 1982). The nature of this strain response and the relationship between the folds generated by regional strain and those produced by forceful emplacement of plutons is unknown. The inferred change in crustal level from southwest to northeast in the Central Maine Terrane will significantly control the character and timing of regional metamorphism across the orogen.

\section{MERRIMACK TROUGH}

The Merrimack Trough is composed of multiply deformed and complexly metamorphosed turbidites (Kittery, Eliot and Berwick formations) that are of enigmatic age and stratigraphic sequence (Bothner et al., 1984; W.A. Bothner and J.B. Lyons, personal communication, 1988). The section is intruded by posttectonic Middle Ordovician diorites, the Exeter and Newburyport complexes, and by the Silurian Ayer granodiorite (Bothner et al., 1984; Zartman and Naylor, 1984; Gaudette et al., 1984). Bothner et al. (1984) have argued that the metasedimentary rocks of the Merrimack Trough pass gradationally into the Massabesic Gneiss Complex, which has been dated as Late Precambrian (Aleinikoff et al., 1979). Therefore the best age assignment for Merrimack Trough sediments is at least pre-Middle Ordovician and probably Precambrian (Gaudette et al., 1984; Bothner et al., 1984). In addition to the Middle Ordovician Exeter and Newburyport diorites and the Silurian Ayer granodiorite, the metasedimentary rocks of the Merrimack Trough are intruded by post-tectonic, Devonian, Carboniferous, and Permian granitoid rocks, many of which are two-mica granites (Lyons et al., 1986).

Three folding events have been recognized in the Merrimack Trough. Early recumbent nappe-stage folds were twice refolded (Hussey et al., 1986). Because the Middle Ordovician Exeter diorite cuts these structures, the age of deformation is pre-Middle Ordovician or possibly Precambrian (Bothner et al., 1984; Gaudette et al., 1984). Bothner et al. (1988) have geophysical evidence to suggest the Merrimack Trough consists of anastamosing fault slivers which may have been operative in the Alleghenian.

Some of the units in the Merrimack Trough (the Berwick Formation in particular) are extremely similiar in lithology to Late Ordovician to Early Devonian formations in the Central Maine Terrane, particularly the Vassalboro Formation of Maine and the Paxton and Oakdale formations of Massachusetts. Furthermore, these units are juxtaposed just across the Nonesuch River fault zone. If these units do correlate, then there is a possibility of a Late Ordovician to Early Devonian depositional age for the Merrimack Trough sediments despite the available radiometric ages on cross-cutting plutons (Hussey, 1985; Hussey et al., 1986; Barosh et al., 1981). In that case, the need for a major terrane boundary between the Central Maine Terrane and Merrimack Trough becomes moot (Hussey, 1985; Hussey et al., 1986).

Sedimentologic evidence argues for the existence of two 


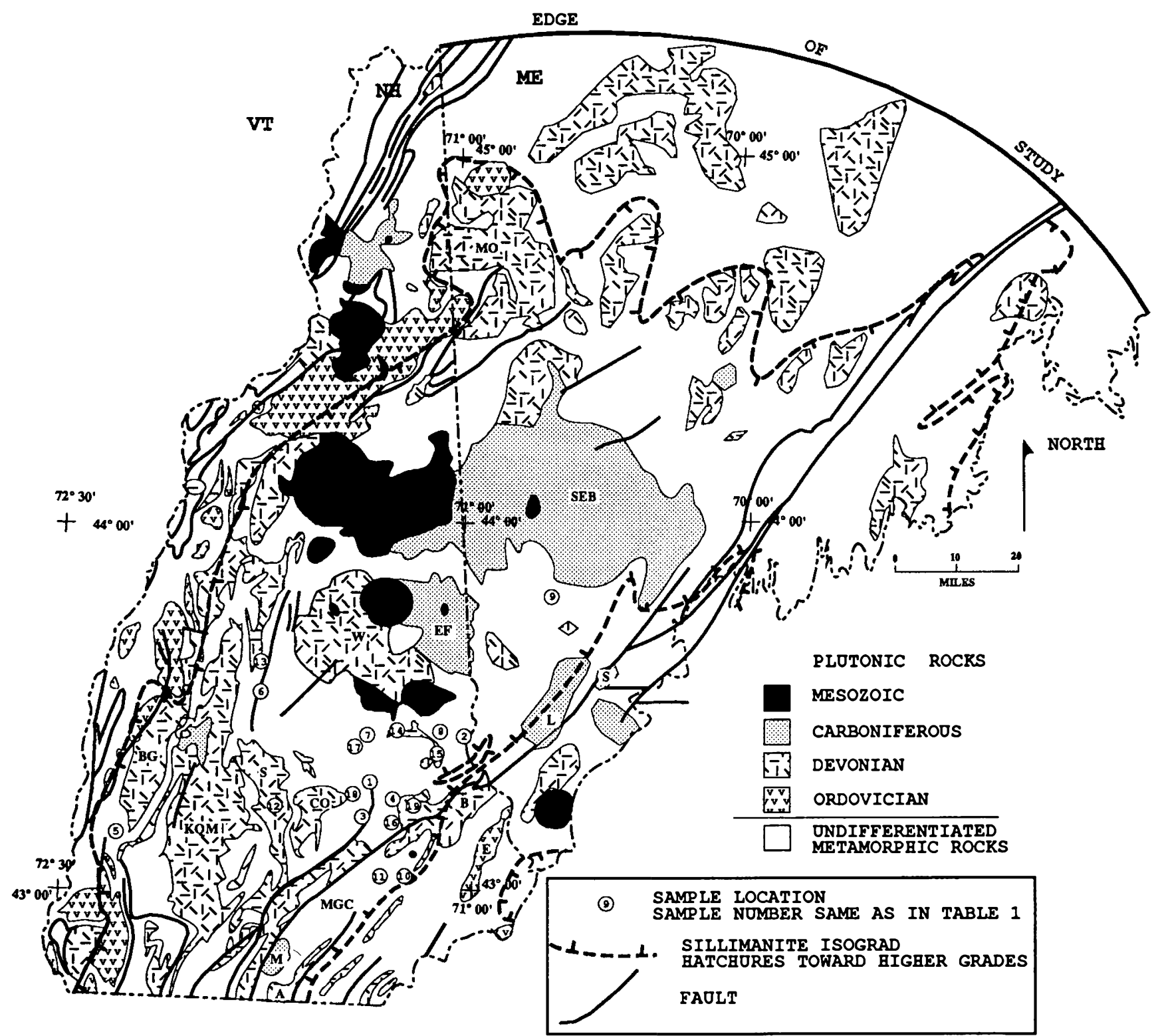

Fig. 2. Simplified geologic map of New Hampshire and southwestem Maine modified from Lyons et al. (1986) and Osberg et al. (1985). Pluton abbreviations: A - Ayer; B - Barrington; BG - Bethlehem Gneiss; CO - Concord; EF - Effingham; E - Exeter; KQM - Kinsman Quartz Monzonite; L - Lyman; M - Milford; MO - Mooselookmeguntic; SEB - Sebago; S - Saco; MGC - Massabesic Gneiss Complex.

distinct terranes. Paleocurrent indicators in the Kittery Formation of the Merrimack Trough show that the source of these sediments was from the east, the site of the present Atlantic ocean (Rickerich, 1983; Hussey et al., 1986). This is opposite from the source direction of the Silurian Central Maine Terrane sequence which was centered roughly over the Bronson Hill Anticlinorium (Hatch et al., 1983). Based on the available radiometric and sedimentologic data, we favor the two-terrane hypothesis.

Northwest of the Merrimack Group lies the Massabesic Gneiss Complex. It is bounded on the northwest by a thin belt of Berwick Formation and in turn by the Campbell Hill-Nonesuch River-Norumbega fault zone. The Massabesic gneiss is composed of migmatites interpreted to consist of ortho- and paragneisses. The $-650 \mathrm{Ma}$ paragneiss is thought to be the high-grade equivalent of the Berwick Formation based on lithic similiarities and gradations between the two (Gaudette et al., 1984; Bothner et al., 1984; Olszewski and Gaudette, 1988; Aleinikoff et al., 1979). Also present are 650 and $475 \mathrm{Ma}$ orthogneisses thought to be of igneous, possibly metavolcanic origin, based on zircon morphology, contact relations with the paragneiss, and the presence of a wide variety of xenoliths(Bothner et al., 1984; Aleinikoff et al., 1979).

Of particular interest in our study is the Permian age (275 $\mathrm{Ma}$ ), based on zircon U-Pb geochronology, of a granite at Milford, New Hampshire which cuts the Massabesic Gneiss Complex, and a discordant Permian (250 Ma) monazite age from Massabesic paragneiss adjacent to the granite at Milford as reported by Aleinikoff et al. (1979). These have been interpreted as vestiges of Alleghenian (Permian) orogenesis, similiar to that reported in Rhode Island but, at that time, not recognized in other 
parts of New England (Aleinikoff $e t$ al., 1979). The possibility of more widespread Alleghenian/Permian deformation and metamorphism throughout much of New England has been recently promoted by Gromet (1988).

\section{TIMING OF HIGH-GRADE METAMORPHISM}

As shown on Figure 2 the upper amphibolite facies regional metamorphic terrane terminates to the northeast in Maine and extends southeast through New Hampshire into Massachusetts and Connecticut. The age of high-grade metamorphism has historically been considered Acadian (i.e., Devonian) (Billings, 1956; Thompson and Norton, 1968) and recent compilations continue to show the peak high-grade assemblages in this area as Acadian (Robinson, 1986). The sillimanite isograd, outlining the metamorphic plateau (shown on Figure 2), crosses many of the aforementioned tectonostratigraphic terrane boundaries with little or no offset (Hussey, 1985; Newberg, 1986 and references cited within). Many of the terranes are juxtaposed along these boundaries at identical sillimanite metamorphic grade (Bothner et al., 1988 and 1984).

If the metamorphic plateau was formed during a single episode of regional metamorphism, the simplest conclusion is that the terranes were assembled in pre-Acadian time and subsequently experienced regional metamorphism during the Devonian. Later events caused only minor shuffling of the isograds and bedrock along the terrane boundaries.

However, within the Central Maine Terrane, recent work suggests that timing of peak high-grade metamorphism varied across the area. Lux and Guidotti (1985) show that some of the peak high-grade metamorphism in the Central Maine Terrane near the Sebago batholith is Hercynian (Alleghenian?) and not Acadian. Furthermore, new radiometric ages that can be interpreted as constraints on the timing of high-grade metamorphism show that rocks at the same metamorphic grade in different terranes were metamorphosed at different times. For example, West et al. (1988a, b) report Permian and Carboniferous metamorphic ages from the Cushing Formation and Olszewski and Gaudette (1988) and Gaudette et al . (1984) reported a Cambrian metamorphic event within the Merrimack Trough.

These data, all from the same metamorphic plateau, suggest that: (1) within a single terrane, the mapped regional isograds are composite, although they do not appear so; (2) the view that this high grade metamorphic plateau formed exclusively during the Acadian may not be correct; and (3) the ages of peak high-grade metamorphism may help constrain the tectono-thermal history of the terranes in this composite region.

\section{U-Pb GEOCHRONOLOGY}

To determine the timing of high-grade metamorphism, we have used the $\mathrm{U}-\mathrm{Pb}$ system in monazite and sphene from sillimanite- or higher grade metasedimentary rocks. We have also dated monazite from peraluminous granites to assess the spatial and temporal relationships between metamorphism and plutonism. The advantage in dating high-grade metamorphism with monazite and sphene in this region is that there is an abundance of monazite-bearing, sillimanite-grade, pelitic schists with subsidiary sphene-bearing calc-silicate units. The lack and/or scarcity of homblende-bearing mafic schists precludes the use of ${ }^{40} \mathrm{Ar} /{ }^{9} \mathrm{Ar}$ release spectra on homblendes as an altemative mineral chronometer for dating high-grade metamorphism in much of the region studied. The $\mathrm{U}-\mathrm{Pb}$ ages of monazites from high-grade schists can record the timing of their growth during sillimanitegrade or higher metamorphism rather than an inherited detrital age (Koppel and Grunenfelder, 1975; Koppel et al., 1980; Oberli et al., 1981; Black et al., 1984; Parrish, 1987; and Parrish et al., 1987). The closure temperature of monazite is not well known but is in the range of $675^{\circ}$ to $725^{\circ} \mathrm{C}$ (Koppel and Grunenfelder, 1975; Copeland et al., 1988).

One factor which may affect $\mathrm{U}-\mathrm{Pb}$ ages in monazite is excess radiogenic ${ }^{206} \mathrm{~Pb}$ inherited from excess ${ }^{230} \mathrm{Th}$ derived from the ${ }^{238} \mathrm{U}$ decay chain, which is incorporated into the monazite during crystallization (Scharer, 1984; Scharer et al., 1986). However, unless the $\mathrm{Th} / \mathrm{U}$ ratio in the source material (i.e., the whole rock or mineral precipitating fluid) was abnormally low (an order of magnitude below the terrestrial value of 4), the excess ${ }^{200 \mathrm{~Pb}}$ effect is small in monazites of this age with our calculated $\mathrm{Th} / \mathrm{U}$ ratios. Whole-rock $\mathrm{Th} / \mathrm{U}$ ratios determined using neutron activation analysis on the schists we dated range from 2.0 to 3.0, similiar to analyses reported by Lyons (1964) for the same formations. Therefore, we believe that the excess ${ }^{200} \mathrm{~Pb}$ effect is insignificant among the schists. However, it is a concern for the granites which commonly have higher $\mathrm{Th} / \mathrm{U}$ ratios and measured reverse discordance.

There has been less work on sphene from metasedimentary rocks, though studies of igneous or meta-igneous sphene are common (Tucker et al., 1986; Mattinson, 1982). The closure temperature of the U.Pb system in sphene is estimated to be about $550 \pm 50^{\circ} \mathrm{C}$, close to, but slightly higher than that of the ${ }^{40} \mathrm{Ar} /{ }^{39} \mathrm{Ar}$ system in homblende (Mattinson, 1986).

Gamet-biotite geothermometry and phase relations for the samples we have dated show that the temperatures during metamorphism ranged from $500^{\circ}$ to $700^{\circ} \mathrm{C}$ (Eusden, 1988). This temperature window also agrees with regional estimates of peak metamorphic conditions within the sillimanite plateau (Chamberlain and Lyons, 1983). The current best estimates for the closure temperatures of both monazite and sphene are similiar to the peak metamorphic temperatures in this region. We believe that the $\mathrm{U}-\mathrm{Pb}$ ages of these minerals, which crystallize during metamorphism, closely record the timing of peak high-grade metamorphism (see also Overstreet, 1967). At the very least, the ages may represent cooling ages soon after peak metamorphism.

\section{GEOCHRONOLOGY OF THE SCHISTS AND GNEISSES}

The U-Pb ages of nine high-grade pelitic schists (sillimanitegrade or higher) from the Silurian Rangeley and Perry Mountain formations of the Central Maine Terrane are either concordant within analytical precision or exhibit slight normal discordance (Table 1, Fig. 3, and Appendix 1; sample locations shown on

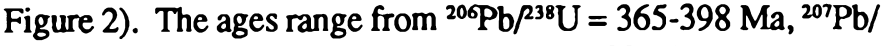
${ }^{23} \mathrm{U}=367-398 \mathrm{Ma}$, and ${ }^{207 \mathrm{~Pb}} /{ }^{206 \mathrm{~Pb}}=376-402 \mathrm{Ma}$. 
Table 1. U-Pb data.

\begin{tabular}{|c|c|c|c|c|c|c|c|c|c|c|c|}
\hline Samplo (4) & $\begin{array}{l}\text { Concentratlon } \\
\text { U, PPm }\end{array}$ & 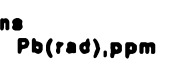 & $\begin{array}{l}\text { Atomle ratlos (1) } \\
200 \mathrm{~Pb} / 204 \mathrm{~Pb}\end{array}$ & $208 \mathrm{~Pb} / 238 \mathrm{U}$ & 207Pb0/238U & $207 \mathrm{~Pb} / 206 \mathrm{~Pb}$ & 208PB./200PB० & $T h / U$ (2) & $208 \cdot 1238$ & 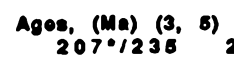 & $207.1200^{\circ}$ \\
\hline 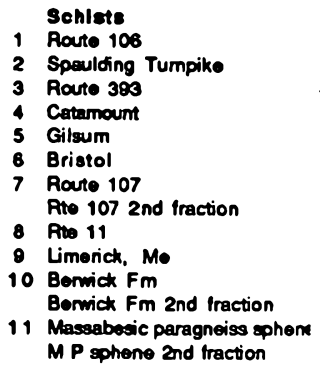 & $\begin{array}{c}3029 \\
9107 \\
7346 \\
4853 \\
5153 \\
1501 \\
8237 \\
4146 \\
3516 \\
3642 \\
2388 \\
2659 \\
149 \\
143 \\
133\end{array}$ & $\begin{array}{l}403 \\
880 \\
1053 \\
633 \\
878 \\
920 \\
520 \\
1018 \\
2147 \\
1757 \\
1520 \\
822 \\
988 \\
54 \\
45\end{array}$ & $\begin{array}{l}14400 \\
38800 \\
19100 \\
17500 \\
17400 \\
11800 \\
19300 \\
21800 \\
10200 \\
38100 \\
4820 \\
4776 \\
366 \\
422\end{array}$ & $\begin{array}{l}0.06098 \\
0.05964 \\
0.06183 \\
0.05896 \\
0.06366 \\
0.06273 \\
0.06018 \\
0.06038 \\
0.05825 \\
0.06149 \\
0.04485 \\
0.04332 \\
0.04248 \\
0.03955\end{array}$ & $\begin{array}{l}0.4568 \\
0.4478 \\
0.4648 \\
0.4493 \\
0.4806 \\
0.4715 \\
0.4507 \\
0.4527 \\
0.4348 \\
0.4604 \\
0.3200 \\
0.3208 \\
0.3101 \\
0.2930\end{array}$ & $\begin{array}{l}0.05435 \\
0.05444 \\
0.05451 \\
0.05443 \\
0.05475 \\
0.05452 \\
0.05432 \\
0.05437 \\
0.05413 \\
0.05431 \\
0.05174 \\
0.05185 \\
0.05294 \\
0.05373\end{array}$ & $\begin{array}{l}1.47 \\
0.99 \\
1.83 \\
1.47 \\
2.39 \\
5.32 \\
1.32 \\
1.35 \\
1.89 \\
0.97 \\
2.99 \\
2.47 \\
0.12 \\
0.22\end{array}$ & $\begin{array}{l}04.6 \\
03.1 \\
05.1 \\
05.5 \\
04.5 \\
07.4 \\
10.5 \\
04.1 \\
04.3 \\
06.0 \\
03.1 \\
03.1 \\
08.3 \\
07.9 \\
00.4 \\
00.7\end{array}$ & $\begin{array}{l}382 \\
373 \\
337 \\
375 \\
308 \\
332 \\
377 \\
378 \\
365 \\
335 \\
283 \\
223 \\
263 \\
268 \\
250\end{array}$ & $\begin{array}{l}382 \\
337 \\
388 \\
377 \\
377 \\
309 \\
392 \\
378 \\
378 \\
379 \\
367 \\
385 \\
282 \\
282 \\
273 \\
274 \\
261\end{array}$ & $\begin{array}{l}385 \\
389 \\
392 \\
389 \\
402 \\
302 \\
384 \\
387 \\
376 \\
384 \\
274 \\
270 \\
326 \\
360\end{array}$ \\
\hline 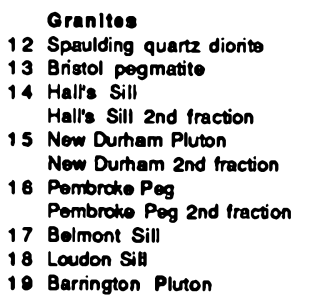 & $\begin{array}{l}2713 \\
4871 \\
2307 \\
1145 \\
4180 \\
1940 \\
2200 \\
671 \\
1519 \\
1634 \\
7543\end{array}$ & $\begin{array}{l}986 \\
438 \\
986 \\
581 \\
1379 \\
1305 \\
1005 \\
1128 \\
348 \\
739 \\
794 \\
3656\end{array}$ & $\begin{array}{c}31700 \\
12500 \\
7918 \\
8540 \\
11300 \\
20800 \\
20062 \\
9522 \\
5724 \\
17300 \\
11800 \\
150000\end{array}$ & $\begin{array}{l}0.06349 \\
0.063655 \\
0.05843 \\
0.0520 \\
0.05913 \\
0.06039 \\
0.05968 \\
0.06041 \\
0.05672 \\
0.05670 \\
0.05653\end{array}$ & $\begin{array}{l}0.4790 \\
0.4787 \\
0.449 \\
0.4412 \\
0.4474 \\
0.4509 \\
0.4440 \\
0.4404 \\
0.4244 \\
0.4498 \\
0.4196\end{array}$ & $\begin{array}{l}0.05472 \\
0.05444 \\
0.05420 \\
0.05405 \\
0.05385 \\
0.05414 \\
0.05398 \\
0.05407 \\
0.05427 \\
0.0537 \\
0.05383\end{array}$ & $\begin{array}{l}5.55 \\
0.58 \\
7.24 \\
6.206 \\
5.37 \\
5.55 \\
3.13 \\
4.6 \\
4.68 \\
3.49 \\
0.04\end{array}$ & $\begin{array}{l}17.2 \\
01.8 \\
22.3 \\
22.2 \\
11.2 \\
17.8 \\
10.0 \\
15.4 \\
14.7 \\
11.1 \\
00.1\end{array}$ & $\begin{array}{l}397 \\
3988 \\
372 \\
377 \\
3770 \\
378 \\
374 \\
378 \\
358 \\
358 \\
354\end{array}$ & $\begin{array}{l}397 \\
397 \\
374 \\
371 \\
368 \\
378 \\
373 \\
373 \\
378 \\
358 \\
356 \\
358\end{array}$ & $\begin{array}{l}401 \\
393 \\
383 \\
373 \\
356 \\
357 \\
374 \\
374 \\
374 \\
382 \\
359 \\
364\end{array}$ \\
\hline
\end{tabular}




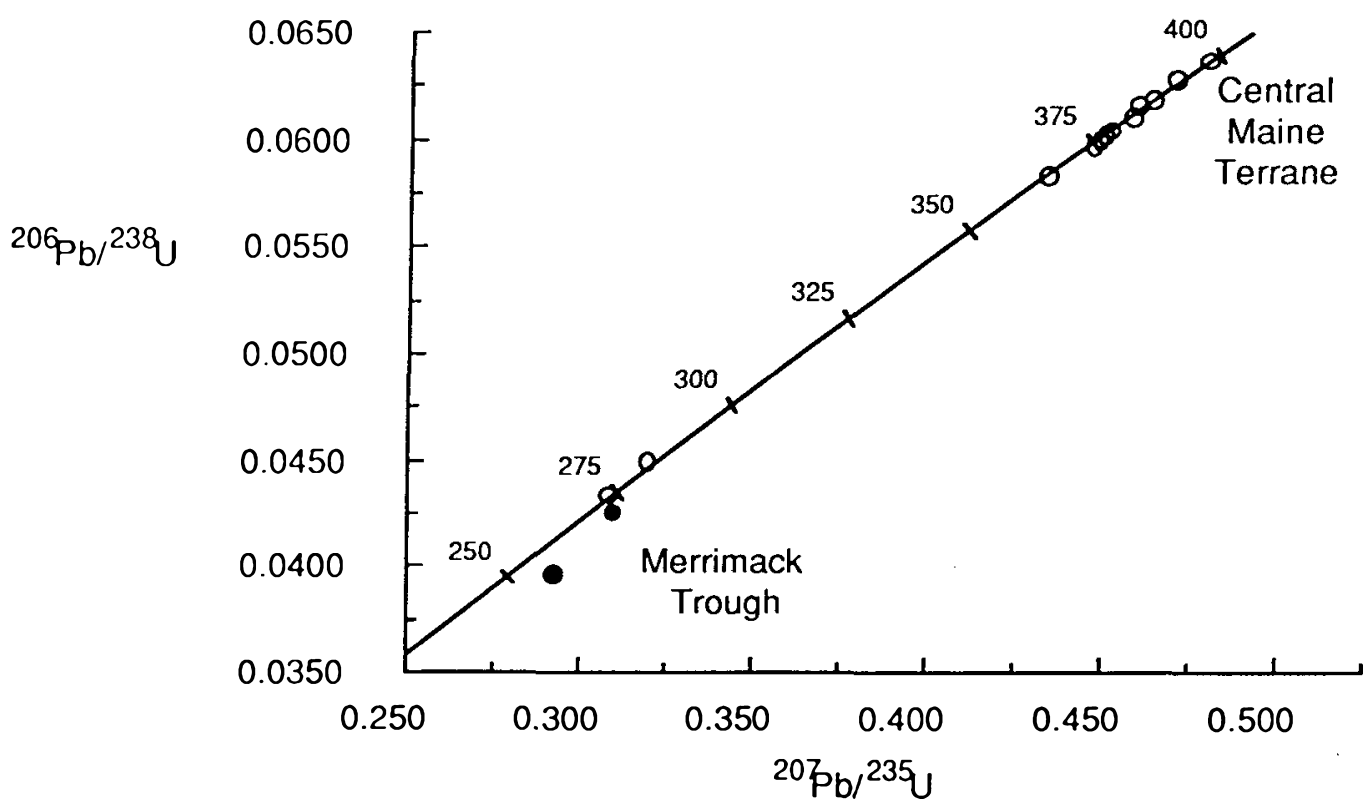

Fig. 3. Concordia plot showing monazite ages from schists in the Central Maine Terrane and monazite and sphene ages from schists in the Merrimack Trough. Open circles - monazite. Filled circles - sphene. Errors smaller than size of circles.

As both excess ${ }^{206 \mathrm{~Pb}}$ and non-modern $\mathrm{Pb}$-loss decrease the ${ }^{207 \mathrm{~Pb}}{ }^{200 \mathrm{~Pb}}$ age, we consider the ${ }^{207 \mathrm{~Pb} /}{ }^{200} \mathrm{~Pb}$ ages as minimum ages. Therefore, the minimum range of metamorphic ages is 376 402. These ages are Acadian (Early to Middle Devonian) and agree well with constraints placed on the timing of regional deformation and metamorphism as inferred by the ages of syntectonic and crosscutting and post-tectonic New Hampshire Series granites (Lyons et al., 1982).

Two fractions of monazite from the sillimanite-grade Berwick Formation have ages of ${ }^{20} \mathrm{~Pb} /{ }^{238} \mathrm{U}=273$ and $293 \mathrm{Ma},{ }^{20} \mathrm{~Pb} /$ ${ }^{23} \mathrm{U}=273$ and $282 \mathrm{Ma}$, and ${ }^{207} \mathrm{~Pb} /{ }^{206} \mathrm{~Pb}=270$ and $274 \mathrm{Ma}$ (Table 1, Fig. 3, and Appendix 1; locations shown on Figure 2). Because these samples are reversely discordant, probably due to excess ${ }^{230} \mathrm{Th}$ rather than U-loss common in high-U minerals, the ${ }^{207 \mathrm{~Pb} /}$ ${ }^{23} \mathrm{~S} U$ age should be considered a minimum age. Two fractions of sphene from the Massabesic gneiss are discordant but have

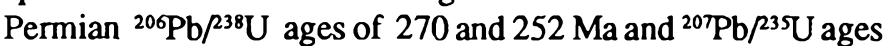
of 276 and $263 \mathrm{Ma}$.

In contrast to the Central Maine Terrane data, U-Pb ages from the Massabesic Gneiss Complex and Merrimack Trough imply that peak high-grade metamorphism was Permian. The two sphenes that were dated can be interpreted as having been disturbed during a Permian event which resulted in recrystallization of new sphene partially or completely resetting older sphene. It is possible that an early, pre-Middle Ordovician metamorphism preceded the Permian metamorphism. Olszewski and Gaudette (1988) suggested that a Cambrian metamorphic-plutonic event is a characteristic of the Merrimack Trough, and Fagan (1986) reported petrographic evidence from the Merrimack Trough suggesting two episodes of metamorphism.

\section{GEOCHRONOLOGY OF THE GRANITES}

We have dated eight granites, seven of which are entirely within the Central Maine Terrane. The eighth is the Barrington granite which is thought to stitch the Campbell Hill-Nonesuch River-Norumbega fault zone. The granite data show a greater incidence of reverse discordance, possibly due to excess ${ }^{200 \mathrm{~Pb}}$. Calculated $\mathrm{Th} / \mathrm{U}$ ratios of monazite from granite (see Table 1 ) are higher than in the schists and gneisses, implying a greater chance for initial ${ }^{230}$ Th disequilibrium. The following discussion will use only the ${ }^{207 \mathrm{~Pb}}{ }^{200 \mathrm{~Pb}}$ ages for normally discordant samples and ${ }^{20} \mathrm{~Pb} /{ }^{35} \mathrm{U}$ ages for reversely discordant samples. The problems with inherited $\mathrm{Pb}$ (Sawka and Harrison, 1986; Copeland et al., 1988), excess ${ }^{20} \mathrm{~Pb}$ from ${ }^{230} \mathrm{Th}$, and the marked discordancy of the granite samples inhibit us from presenting anything more than generalizations concerning the significance of the granite ages (Table 1). Despite the possible complications with the monazite $\mathrm{U}-\mathrm{Pb}$ systematics, the granite ages range from 393-356 Ma. These ages contribute to the already voluminous data base showing a distinct pulse of Devonian magmatism in the Central Maine Terrane (Table 2).

The Barrington Pluton, also called the Center Strafford Pluton (Lyons, personal communication, 1988), stitching the Campbell Hill-Nonesuch River-Norumbega fault zone, has also been affected by motion in zones parallel to and along the boundary, as evidenced by well developed mylonitic S-C fabrics (Eusden, 1988). The pluton must have experienced only minor offset as it shows insignificant map scale displacement. The monazite ${ }^{207 \mathrm{~Pb}} /{ }^{00} \mathrm{~Pb}$ age of the Barrington is $364 \mathrm{Ma}$. The Lyman (322 Ma) and Saco (307 Ma) granites of southwestern Maine are 
Table 2. Timing of plutonism in the Central Maine Terrane as compared to the Merimack Trough/Messabesic Gneiss based on available radiometric ages.

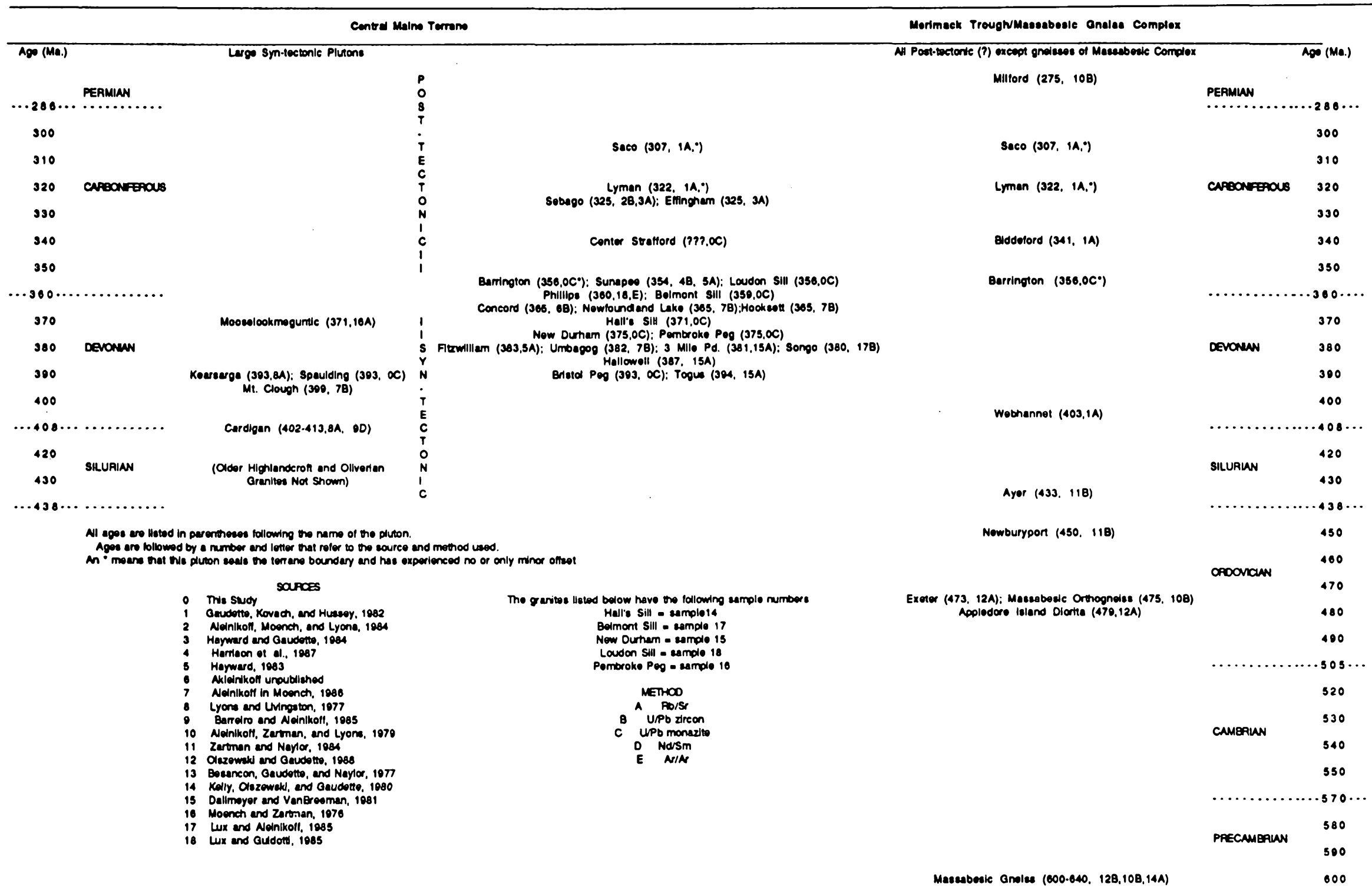


also in this family of plutons that stitch the fault and show minor offset (Gaudette et al., 1982; Hussey, 1985). The Barrington is then the oldest of the stitching granites and as such places a minimum limit on the time of initial terrane accretion along the Campbell Hill-Nonesuch River-Norumbega fault zone.

\section{DISCUSSION}

\section{Implications for the Central Maine Terrane}

Most of the monazite samples from sillimanite-grade schists of the Central Maine Terrane (except samples 5, 6, and 9) were collected in regions where we have done or are currently doing detailed structural work and petrography. In thin section, monazites from the Central Maine Terrane occur within the pelitic matrix and as inclusions in biotite porphyroblasts. In all samples monazite occurs as inclusions with pleochroic haloes in biotite that define the $S_{1}$ and $S_{2}$ foliations. These fabrics formed during $F_{1}$ (nappe-stage) and $F_{2}$ folding during the early stages of Acadian orogenesis. This textural evidence suggests that monazite growth and high-grade metamorphism occurred early in the Acadian event. The syn-tectonic nature of metamorphism is also well documented in the field; migmatitic layering, equivalent to $S_{1}$, is commonly folded by $\mathrm{F}_{2}$ folds (Eusden, 1988).

Due to the uncertainties in the monazite ages we cannot confidently relate them to discrete folding events in the Central Maine Terrane. However, the data suggest that high-grade metamorphism and deformation occurred simultaneously and that the main pulse of the Acadian event was over by approximately 380 Ma. Similarly, Naylor (1971) has argued that the Acadian was an abrupt and brief event. This is consistent with the timing of the Acadian orogeny as inferred from other isotopic ages of crosscutting plutons in New Hampshire and Maine (Lyons et al., 1986; Osberg et al., 1985). The magmatic pulse of the New Hampshire Plutonic Series overlapped and extended beyond the deformation and metamorphism, lasting from roughly 410 Ma to $355 \mathrm{Ma}$. Table 2 shows this distinct pulse of Devonian magmatism, after which there is a gap until about $325 \mathrm{Ma}$ when the Sebago, Effingham and Lyman plutons intruded. Emplacement of these plutons caused an episode of Carboniferous contact-regional, high-grade metamorphism overprinting the Acadian metamorphism (Lux and Guidotti, 1985).

\section{Implications for the Merrimack Trough}

In the Massabesic gneiss of southern New Hampshire, Aleinikoff et al. (1979) reported a discordant ${ }^{207} \mathrm{~Pb} /{ }^{066} \mathrm{~Pb}$ monazite age of $289 \mathrm{Ma}$, suggesting either the possibility of local resetting due to the intrusion of the 275 Ma granite at Milford, or regional Permian metamorphism. Our monazite and sphene ages from the Berwick Formation and Massabesic gneiss suggest Permian regional high-grade metamorphism in this terrane. The $473 \mathrm{Ma}$ Exeter pluton cut and imparted a narrow contact aureole to low-grade rocks. The low-grade metasedimentary rocks are thought to be part of the regional metamorphism reaching sillimanite-grade within the Massabesic. Therefore, based on the age of the Exeter pluton, the Merrimack Trough experienced an earlier, pre-Middle Ordovician(?) metamorphism (Bothner $e t$ al., 1984). Disequilibrium petrographic textures observed by Fagan (1986) in high-grade rocks of the Merrimack Trough support polymetamorphism but do not provide age discrimination.

The possibility of a distinct Permian event restricted to the Merrimack Trough would appear to constrain the westward limit of the Alleghenian or Variscan Front in northern New England. This Late Carboniferous to Early Permian orogenic event is well established in the central and southern Appalachians and has been documented in southeastern New England (Zartman et al., 1988). However, until now, little evidence pointed to its existence in the classic Acadian and Taconian terranes of northern New England. Gromet (1988) has suggested that the Late Paleozoic tectonism documented in southeastern New England may have occurred farther north. Gromet also suggested that a major Alleghenian imprint on the Masssabesic Gneiss Complex should be considered. Based on the contrasting monazite ages across the Campbell Hill-Nonesuch River fault zone, this boundary is the most likely candidate for the Variscan or Alleghenian Front.

\section{Timing of High-Grade Metamorphism and Terrane Accretion}

Within the high-grade terrane shown on Figures 2 and 4, different age estimates of peak high-grade metamorphism have been proposed. They are summarized on Table 3 and Figure 4. There is a rather confusing picture of the timing of peak highgrade regional metamorphism from an area where, historically, all was thought to be Acadian. The ages of metamorphism for the proposed terranes and even within a single terrane, for example the Central Maine Terrane, range considerably.

Lux and Guidotti (1985) reported ${ }^{40} \mathrm{Ar}-{ }^{39} \mathrm{Ar}$ homblende ages of 305 to $310 \mathrm{Ma}$ from rocks in the central-western Maine part of the Central Maine Terrane and suggested that much, if not all, of the high-grade metamorphism there was Hercynian (325 Ma) and not Acadian in age. Gromet (1988) suspected that widespread Alleghenian (or Hercynian) metamorphism occurred throughout the metamorphic belt of New England as far west as the Bronson Hill Anticlinorium based on preliminary $\mathrm{Rb}-\mathrm{Sr}$ dating and observations in southeastern Massachusetts and Rhode Island. Dallmeyer reported ${ }^{40} \mathrm{Ar}-{ }^{39} \mathrm{Ar}$ homblende ages of 350 to $330 \mathrm{Ma}$ from south-central Maine and concluded that the age of peak high-grade metamorphism is Acadian, or approximately $380 \mathrm{Ma}$ (Dallmeyer, 1979; Dallmeyer and van Breemen, 1981). Our monazite ages indicate that the age of high-grade metamorphism was Acadian in central New Hampshire.

In the Coastal Lithotectonic Block, results of several geochronologic studies bracket the timing of peak high-grade metamorphism. West et al. $\left(1988 \mathrm{a}\right.$, b) reported ${ }^{40} \mathrm{Ar}-{ }^{39} \mathrm{Ar}$ homblende ages from the Falmouth-Brunswick Belt, part of the Casco Bay Group (Fig. 1). The northeastern part of the belt has ages of 367 to $377 \mathrm{Ma}$, whereas the southwestern part has ages of 280 to 290 Ma. This belt includes the Cushing Formation, a basement complex often equated with the Massabesic gneiss (Hussey, 1985). Southeast of the Flying Point fault in the Saco-Harpswell 


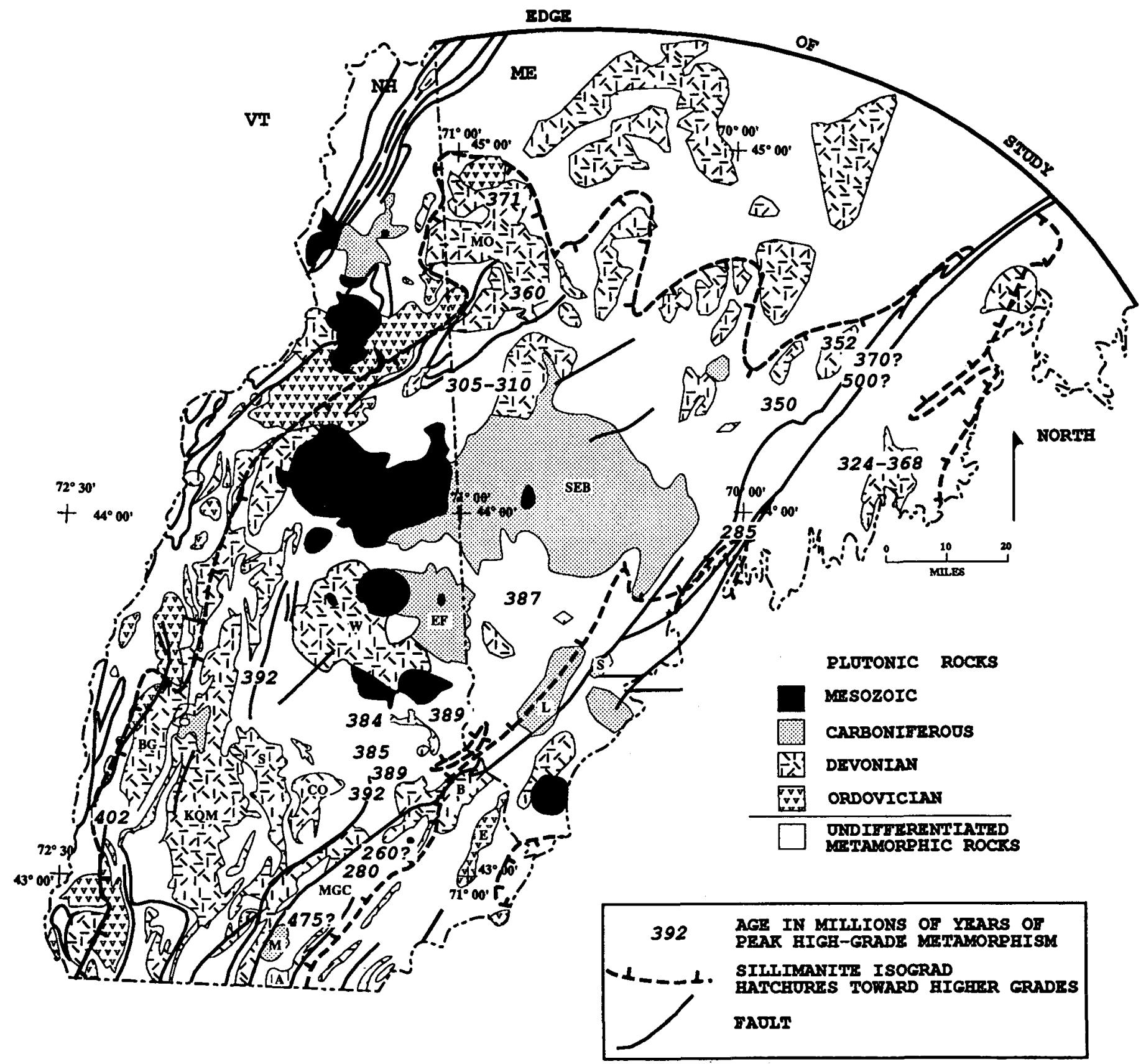

Fig. 4. Simplified geologic map of New Hampshire and southwestem Maine. Plateau of high-grade metamorphism enscribed by the sillimanite isograd. Available radiometric ages of peak high-grade metamorphism are plotted. Ages of metamorphism show considerable spread within the high-grade plateau. Even within discrete terranes the age of peak high-grade metamorphism varies. Abbreviations same as in Figure 2.

area, or part of what is termed here the "Casco Bay Block", ${ }^{40} \mathrm{Ar}$ ${ }^{39} \mathrm{Ar}$ hornblende ages range from 324 to $368 \mathrm{Ma}$ (West et al., 1988). Olszewski and Gaudette (1988) reported a Rb-Sr whole rock age of $495 \mathrm{Ma}$ from the Cushing Formation and suggested that a unique period of intrusion and metamorphism from 540 to $470 \mathrm{Ma}$ is characteristic of the rocks southeast of the Campbell Hill-Nonesuch River-Norumbega fault zone. Brookins and Hussey (1978) reported Rb-Sr whole rock ages of $481 \mathrm{Ma}$ for the Cushing and 539 to $485 \mathrm{Ma}$ for the rocks of the "Casco Bay Block." Our monazite and sphene ages suggest Permian highgrade metamorphism in the Merrimack Trough. The ages of high-grade metamorphism span the Cambrian through Permian and it is interesting that Permian metamorphism appears in both the Cushing and Massabesic gneiss complexes, suggestive of significant regional metamorphism in the basement rocks at this time.

The overall history of the high-grade zone must be complex. The available radiometric ages constrain several aspects concerning the existence and tectono-metamorphic histories of the proposed terranes. First, monazite ages from schists are markedly different across the Campbell Hill-Nonesuch River-Norumbega fault zone; Acadian in the Central Maine Terrane and 
Table 3. Timing of peak high-grade metamorphism in New Hampshire and Maine based on available radiometric ages.

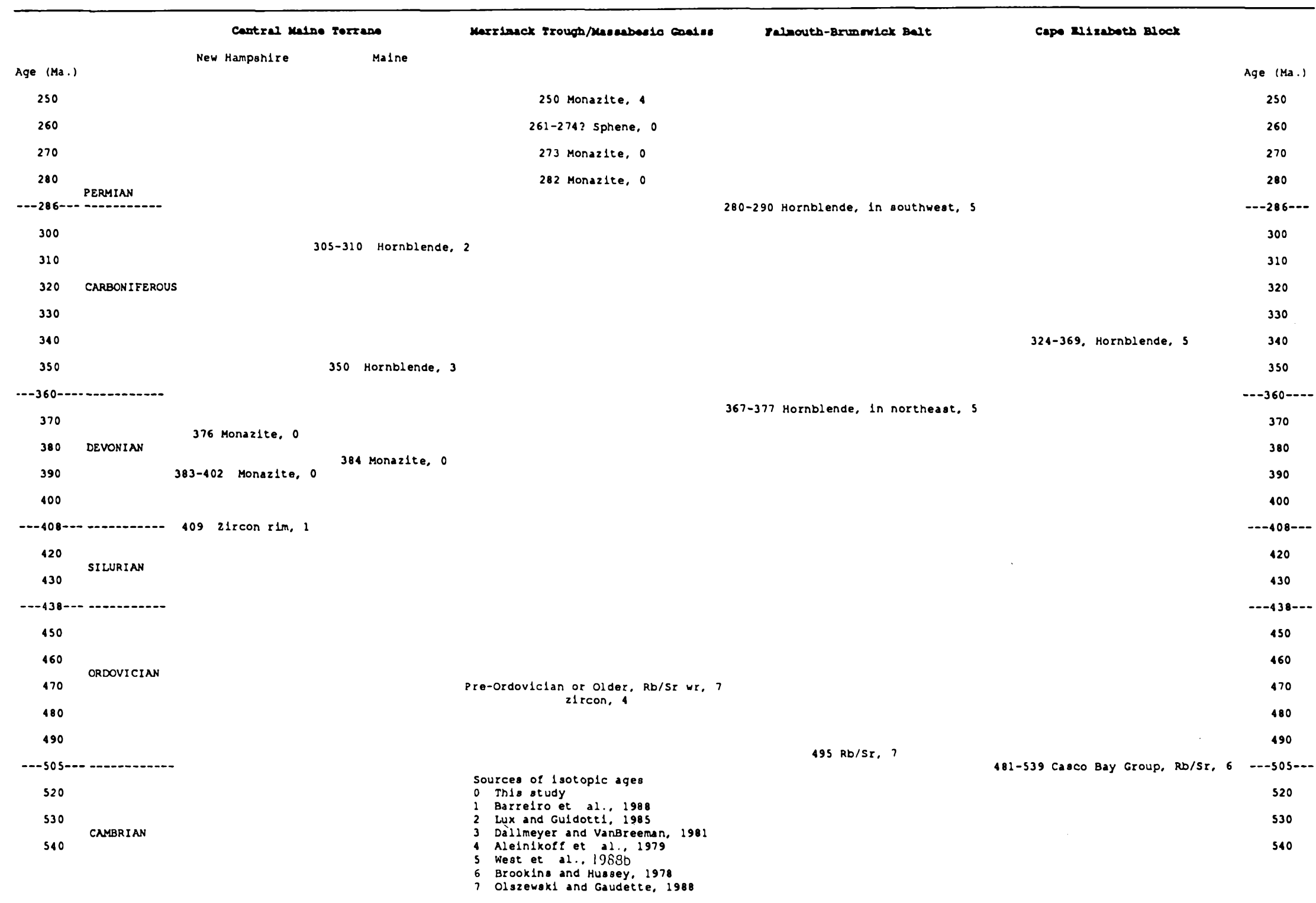


Permian in the Merrimack Trough. Second, the Central Maine Terrane experienced a distinct pulse of Devonian magmatism that the Merrimack Trough did not. Finally, the Barrington (364 $\mathrm{Ma})$, Lyman (322 Ma) and Saco (307 Ma) plutons that stitch the terrane-bounding Campbell Hill-Nonesuch River-Norumbega fault zone have undergone at least minor deformation but show no major offset. However, the radiometric ages suggest that significant motion must have occurred along the fault to juxtapose the cooled Acadian high-grade rocks against the Permian high-grade rocks.

From our results and compilation we suggest the following tectono-metamorphic history for the Central Maine Terrane. Acadian plutonism, metamorphism and deformation occurred immediately after deposition of the Siluro-Devonian sediments (see also Naylor, 1971). High-grade metamorphism and early deformation was completed by about $380 \mathrm{Ma}$; plutonism ended at about $355 \mathrm{Ma}$ and then was renewed in the Carboniferous ( $\sim 325 \mathrm{Ma})$ causing contact-regional metamorphism in Maine. The late stages of deformation in the Central Maine Terrane may have extended into the Carboniferous (Alleghenian).

The Merrimack Trough experienced pre-Middle Ordovician high-grade metamorphism and deformation prior to accretion with the Central Maine Terrane. There appears to be no record of the Acadian orogeny in the Merrimack Trough. Initial accretion of the Merrimack Trough and Central Maine Terrane $\alpha$ curred just before the intrusion of the Barrington Pluton ( 365 Ma) because (1) this pluton stitches the fault, and (2) if accretion occurred any earlier the Merrimack Trough would have experienced some of the characteristic Devonian magmatism of the Central Maine Terrane. Furthermore, Acadian $\mathrm{F}_{2}$ axial traces are clearly truncated by the Campbell Hill-Nonesuch River-Norumbega fault zone (Eusden et al., 1987), suggesting that accretion was post $-\mathrm{F}_{2}$ folding.

Following accretion, the Campbell Hill-Nonesuch RiverNorumbega fault zone remained active through at least the late Carboniferous as constrained by the age of the Saco pluton (307 Ma) which stitches but is also cut by the fault. The Merrimack Trough then experienced Permian magmatism locally, as well as high-grade metamorphism. The rocks in the Central Maine Terrane were not affected by this younger metamorphism. Permian K-Ar muscovite ages (Zartman et al., 1970) suggest that the Central Maine Terrane was several hundred degrees cooler than the Merrimack Trough in the Permian. Sufficient movement must have occurred along the fault to juxtapose the cooled Acadian and presumably hot Permian high-grade terranes. This is a quandry because the movement had to be sufficient vertically to cause the juxtaposition but little horizontally so as not to significantly offset the Barrington, Lyman and Saco plutons.

It seems likely that the postulated Permian metamorphic overprint in the Merrimack Trough and Cushing Formation is a result of Late Paleozoic Alleghenian or Variscan sliver tectonism as suggested by Bothner et al. (1988). However, the final juxtaposition of basement complexes and cover sequences must have been later, Late Permian or Early Triassic. At this time, the tectonic regime in New England became extensional. If the basement-bounding faults moved substantially in the Mesozoic, they were probably extensional rather then compressional or transpressional. The faults could have been thrusts or strike-slip faults in the Acadian through Alleghenian, later switching sense of motion. An analogous scenario involving multiple motions along similiar terrane-bounding faults has been documented by Goldstein (1988) in southeastern New England. The basement complexes (Massabesic gneiss and Cushing Formation, and perhaps the Rye and Passagassawakeag gneisses) may have evolved structurally like the basement exposed in Cordillerian metamorphic core complexes. Historically, extensional tectonics in New England generally have not been regarded as a viable alternative when explaining the deformation and metamorphism seen in the Paleozoic and Precambrian rocks. Nevertheless, this alternative is worth considering, and requires detailed structural analysis along the terrane boundaries and geochronologic studies within the proposed terranes.

\section{CONCLUSIONS}

Ages of peak metamorphism from the Central Maine Terrane and Merrimack Trough are Devonian and Permian, respectively. The ages support the hypothesis that these are separate terranes with distinct tectono-metamorphic histories coincidentally juxtaposed at the same metamorphic grade.

The high-grade terrane of this part of the Appalachians is composite. It is made up of crustal blocks that experienced discrete pulses of high-grade metamorphism beginning as long ago as the pre-Middle Ordovician and extending into the Permian.

The Campbell Hill-Nonesuch River-Norumbega fault zone has had an active and complex history, from the late Devonian to the Mesozoic. This boundary is a likely candidate for the Alleghenian (Variscan) Front in New England.

Mesozoic extension was the last type of motion along the terrane boundary between the Central Maine Terrane and Merrimack Trough. The fault may be a reactivated Acadian/Alleghenian compressional /transpressional structure.

\section{ACKNOWLEDGEMENTS}

Weare grateful to reviews of this paperby JohnN. Aleinikoff, Wallace A. Bothner, and John B. Lyons from which we have benefited considerably. This work was partially supported by National Science Foundation grants (EAR-8416640 and EAR8721174 ) to Lyons and Barreiro. We thank George Tilton and Jim Mattinson for use of the mass spectrometer at University of California, Santa Barbara and for thoughtful discussion on monazite systematics.

ALEINIKOFF, J.N.,ZARTMAN, R.E., and LYONS, J.B. 1979. U-Th$\mathrm{Pb}$ geochronology of the Massabesic gneiss and the granite near Milford, south-central New Hampshire: new evidence for Avalonian basement and Taconic and Alleghenian disturbances in eastem New England. Contributions to Mineralogy and Petrology, 71, pp. 1-11.

ALEINIKOFF, J.N., MOENCH, R.H., and LYONS, J.B. 1984. Carboniferous U-Pb age of the Sebago Batholith, southwestern Maine: Metamorphic and tectonic implications. Geological Society of America, Bulletin 96, pp. 990-996. 
BAROSH, P. and PEASE, M.H., JR. 1981. Correlation of the Oakdale and Paxton Formations with their equivalents from Eastern Connecticut to southern Maine. Geological Society of America, Abstracts with Programs, 13, p. 122.

BARREIRO, B., ZEITLER,P., CHAMBERLAIN,C.P., and RUMBLE, D., III. 1988. Dating fluid transport in the lower crust: Acadian U$\mathrm{Pb}$ ages of zircon and monazite from the Bristol, New Hampshire metamorphic hotspot. Transactions, American Geophysical Union, EOS, p. 464.

BARREIRO, B. and ALEINIKOFF, J.N. 1985. Sm-Nd and U-Pb isotopic relationships in the Kinsman quartz monzonite, New Hampshire. Geological Society of America, Abstracts with Programs, 17, p. 3.

BESANCON, J.R., GAUDETTE, H.R., and NAYLOR, R.S. 1977. Age of the Massabesic Gneiss, Southern New Hampshire. Geological Society of America, Abstracts with Programs, 9, p. 242.

BILLINGS, M.P. 1956. The geology of New Hampshire: Part II Bedrock geology. New Hampshire State Planning and Development Commission, 203 p.

BLACK, L.P., FITZGERALD, J.D., and HARLEY, S.L. 1984. Pb isotopic composition, colour, and microstructure of monazites from a polymetamorphic rock in Antarctica. Contributions to Mineralogy and Petrology, 85, pp. 141-148.

BOTHNER, W.A., BOUDETTE, E.L., FAGAN, T.J., GAUDETTE, H.E., LAIRD, J., and OOLSZEWSKI, W.J. 1984. Geologic framework of the Massabesic Anticlinorium and the Merrimack Trough, southeastern New Hampshire. In Geology of the coastal lowlands: Boston, MA to Kennebunk, ME. Edited by L.S. Hanson. New England Intercollegiate Geologic Conference, pp. 186-206.

BOTHNER, W.A., BROOKS, J.A., and EUSDEN, J.D., JR. 1988. Geology and geophysics of the Massabesic, Merrimack and Rye "Zones" in Central Coastal New England. Geological Society of America, Abstracts with Programs, 20, p. 9.

BROOKINS, D.G. and HUSSEY, A.M., II. 1978. Rb-Sr ages for the Casco Bay Group and other rocks from the Portland-Orrs Island area, Maine. Geological Society of America, Abstracts with Programs, 10, p. 34.

CHAMBERLAIN, C.P. and LYONS, J.B. 1983. Pressure, temperature and metamorphic zonation studies of pelitic schists in the Merrimack Synclinorium, south-central New Hampshire. American Mineralogist, 68, pp. 530-540.

COPELAND, P., PARRISH, R.P., and HARRISON, T.M. 1988. Identification of inherited radiogenic $\mathrm{Pb}$ in monazite and its implications for the U-Pb systematics. Nature, 333, pp. 760-763.

DALLMEYER, R.D. and VanBREEMAN, O. 1981. Rb-Sr whole rock and ${ }^{40} \mathrm{Ar} /{ }^{99} \mathrm{Ar}$ mineral ages of the Togus and Hallowell quartz monzonite and Three Mile Pond granodiorite plutons, southcentral Maine: Their bearing on post-Acadian cooling history. Contributions to Mineralogy and Petrology, 78, pp. 61-73.

DALLMEYER, R.D. 1979. Chronology of igneous and metamorphic activity in south-central Maine. In Geological excursions in the northeast Appalachians. Edited by J.W. Skehan and P.H. Osberg. IGCP Project 27, Weston Observatory, Weston, pp. 63-71.

EUSDEN, J.D. 1988. The Bedrock geology of the Gilmanton 15 minute quadrangle, New Hampshire. Ph.D. thesis, Dartmouth College, $245 \mathrm{p}$.

EUSDEN, J.D., BOTHNER, W.A., and HUSSEY, A.M. 1987. The Kearsarge-Central Maine Synclinorium of southeastern New Hampshire and southwestern Maine: Stratigraphic and structural relations of an inverted section. American Journal of Science, 287. pp. 242-264.

FAGAN, T.J. 1986. Metamorphic petrology and structure of a transcet from the Berwick Formation into the Massabesic Gneiss Complex, southeastern New Hampshire. M.Sc. thesis, University of New Hampshire, 108 p.

GAUDETTE, H.E., KOVACH, A., and HUSSEY, A.M., I. 1982. Ages of some intrusive rocks of southwestem Maine, U.S.A. Canadian Joumal of Earth Sciences, 19, pp. 1350-1357.

GAUDETTE, H.E., BOTHNER, W.A., LAIRD, J., OLSZEWSKI, W.J., JR., and CHEATHAM, M.M. 1984. Late Precambrian/Early Paleozoic deformation and metamorphism in southeastem New Hampshire - Confirmation of an exotic terrane. Geological Society of America, Abstracts with Programs, 16, p. 516.

GOLDSTEIN, A.G. In press. Tectonic significance of multiple motions on terrane-bounding faults in the Northern Appalachians. American Joumal of Science.

GROMET, L.P. 1988. A different perspective on the Alleghanian orogeny in the New England Appalachians. Geological Society of America, Abstracts with Programs, 20, p. 24.

HALL, B.A., POLLACK, S.G., and DOLAN, K.M. 1976. Lower Devonian Seboomook Formation and Matagamon sandstone, northem Maine: A flysch basin-margin delta complex. In Contributions to the stratigr aphy of New England. Edited by L.R. Page. Geological Society of America, Memoir 148, pp. 57-63.

HANSON, L.S. and SAUCHUK, S. 1986. Lithofacies and paleoflows of the Carrabassett and Seboomook Formations, north-central Maine. Geological Society of America, Abstracts with Programs, 18, p. 21.

HARRISON, T.M., AlLEINIKOFF, J.N., and COMPSTON, W. 1987. Observations and controls on the occurrence of inherited zircon in Concord-type granitoids, New Hampshire. Geochimica et Cosmochimica Acta, 51, pp. 2549-2558.

HATCH, N.L., MOENCH, R.H., and LYONS, J.B. 1983. SilurianLower Devonian stratigraphy of eastem and south-central New Hampshire: Extensions from western Maine. American Joumal of Science, 283, pp. 739-761.

HAYWARD, J.A. 1983. Rb-Sr geochronology and the evolution of some peraluminous (two-mica) granites in New Hampshire. Geological Society of America, Abstracts with Programs, 15, p. 146.

HAYWARD, J.A. and GAUDETTE, H.E. 1984. Carboniferous age of the Sebago and Effingham Plutons, Maine and New Hampshire. Geological Society of America, Abstracts with Programs, 16, p. 22.

HODGE, D.S., ABBEY, D.A., HARBIN, M.A., PATTERSON, J.L., RING, M.J., and SWEENEY, J.F. 1982. Gravity studies of subsurface mass distributions of granitic rocks in Maine and New Hampshire. American Journal of Science, 282, pp. 1289-1324.

HUBACHER, F.A. and LUX, D.R. 1987. Timing of Acadian deformation in northeastern Maine. Geology, 15, pp. 80-83.

HUSSEY, A.M., II. 1985. The bedrock geology of the Bath and Portland $2^{\circ}$ Sheets. Maine Geological Survey, Open File Report 85-87, 82 p.

HUSSEY, A.M., BOTHNER, W.A., and THOMSON, J. 1986. Geological comparisons across the Norumbega Fault Zone, southwestem Maine. In Guidebook for field-trips in southwestern Maine. Edited by D.W. Newburg. N.E.I.G.C., Trip A-4, pp. 53-79.

KELLY, W.J., OLSZEWSKI, W.J., and GAUDETTE, H.E. 1980. The Massabesic Orthogneiss, southem New Hampshire. Geological Society of America, Abstracts with Programs, 12, p. 45.

KOPPEL, V. and GRUNENFELDER, M. 1975. Concordant U-Pb ages of monazite and xenotime from the Central Alps and the timing of the high temperature Alpine metamorphism, a preliminary report. Schweizerische Mineralogische und Petrographische Mitteilungen, 55. pp. 129-132. 
KOPPEL, V., GUNTHERT, A., and GRUNENFELDER, M. 1980. Patterns of $\mathrm{U}-\mathrm{Pb}$ zircon and monazite ages in polymetamorphic units of the Swiss Central Alps. Schweizerische Mineralogische und Petrographische Mitteilungen, 60, pp. 97-119.

KROGH, T.E. 1973. A low contamination method for hydrothermal decomposition of zircon and extraction of $\mathrm{U}$ and $\mathrm{Pb}$ for isotopic determination. Geochimica et Cosmochimica Acta, 37, pp. 485494.

LUX, D.R. and GUIDOTTI, C.V. 1985. Evidence for extensive Hercynian metamorphism in westem Maine. Geology, 13, pp. 696700.

LUX, D.R. and ALEINIKOFF, JN. 1985. ${ }^{40} \mathrm{Ar}-{ }^{39} \mathrm{Ar}$ and U-Pb geochronology of the Songo pluton, western Maine. Geological Survey of America, Abstracts with Programs, 17, p. 32.

LYONS, J.B. 1964. Distribution of thorium and uranium in three early Paleozoic plutonic series of New Hampshire. United States Geological Survey, Bulletin 1144-F, 76 p.

LYONS, J.B., BOUDETTE, E.L., and ALEINIKOFF, J.N. 1982. The Avalon and Gander zones in central eastern New England. In Major structural zones and faults of the northem Appalachians. Edited by P. St. Julien and J. Beland. Geological Association of Canada, Special Paper No. 24, pp. 43-66.

LYONS, J.B., BOTHNER, W.A., MOENCH, R.H., and THOMPSON, J.B. 1986. Bedrock Geologic Map of New Hampshire. Open File Report 86-1, State Geologists Office, Durham, New Hampshire.

LYONS, J.B. and LIVINGSTON, D.E. 1977. Rb-Sr age of the New Hampshire plutonic series. Geological Society of America, Bulletin 88, pp. 1808-1812.

MATTINSON, J.M. 1982. U-Pb "blocking temperatures" and Pb-loss characteristics in young zircon, sphene, and apatite. Geological Society of America, Abstracts with Programs, 14, p. 588.

-1986. Geochronology of high pressure-low temperature Franciscan metabasites: A new approach using the U-Pb system. Geological Society of America, Memoir 168, pp. 95-105.

- 1987. U-Pb ages of zircons: A basic examination of error propagation. Chemical Geology, 66, pp. 151-162.

MOENCH, R.H., BOTHNER, W.A., and CARNESE, M.T. 1982. Nature of the Devonian transition from the upper to middle crust in New England. Geological Society of America, Abstracts with Programs, 14, p. 567.

MOENCH, R.H. and ZARTMAN, R.E. 1976. Chronology and styles of multiple deformation, plutonism, and polymetamorphism in the Merrimack Synclinorium of western Maine. Geological Society of America, Memoir 146, pp. 203-238.

NAYLOR, R.S. 1971. The Acadian Orogeny: An abrupt and brief event. Science, 172, pp. 558-560.

NEWBURG, D. 1986. The Norumbega Fault Zone between Bath and Freedom, Maine. In Guidebook for field trips in southwestern Maine. Edited by D.W. Newburg.. N.E.I.G.C., Trip A-5, pp. 8097.

NIELSON, D.L., CLARK, R.G., LYONS, J.B., ENGLAND, E.J., and BORNS, D.H.. 1976. Gravity models and mode of emplacement of the New Hampshire plutonic series. In Studies of New England geology. Edited by P.C. Lyons and A.H. Brownlow. Geological Society of America, Memoir 146, pp. 301-318.

OBERLI, F., SOMMERAUER, J., and STEIGER, R.H. 1981. U-(Th)$\mathrm{Pb}$ systematics and mineralogy of single crystals and concentrates of accessory minerals from the Cacciola granite, central Gotthard massif, Switzerland. Schweizerische Mineralogische und Petrographische Mitteilungen, 61, pp. 323-348.

OLSZEWSKI, W.J. and GAUDETTE, H.E. 1988. Early Paleozoic thermotectonic history of eastern New England: Cambro-Ordovi- cian metamorphism and plutonism - A distinctive feature of the "Casco" terrane. Geological Society of America, Abstracts with Programs, 20, p. 60.

OSBERG, P.H., HUSSEY, A.M., II., and BOONE, G.M. 1985. Bedrock Geologic Map of Maine. Maine Geological Survey, Augusta, Maine.

OVERSTREET, W.C. 1967. The geologic occurrence of monazite. United States Geological Survey, Professional Paper 530, pp. 1327.

PARRISH, R.R. 1987. Comprehensive geochronology of the Valhalla Complex (VC), an extensional core complex of southeastem British Columbia. Geological Association of Canada-Mineralogical Association of Canada, Abstracts with Programs, 12, p. 78.

PARRISH, R.R., PRICE, R.A., and CARR, S.D. 1987. Late Cretaceous-Paleogene metamorphism in the core zone of the Cordilleran orogen: Valhalla complex of southeastern British Columbia. Geological Society of America, Abstracts with Programs, 19, p. 800.

RICKERICH, S.F. 1983. Sedimentology, stratigraphy and structure of the Kittery Formation in the Portsmouth, New Hampshire area. Unpublished MS, University of New Hampshire, 115 p.

ROBINSON, P. 1987. Root zones of the Acadian Bemardston nappe and Brennan Hill thrust, Mt. Grace area, north-central Massachusetts. Geological Society of America, Abstracts with Programs, 19 , p. 54.

1986. Introduction. In Field trip guidebook: Regional metamorphism and metamorphic phase relations in northwestern and central New England. Edited by P. Robinson. International Mineralogical Association, Contribution No. 59, Department of Geology and Geography, University of Massachusetts, pp. 1-10.

SAWKA. W.N. and HARRISON, T.M. 1986. The interpretation of U$\mathrm{Pb}$ monazite ages from I- and S-type granitoids. Geological Society of America, Abstracts with Programs, 19, p. 64.

SCHARER, U. 1984. The effect of initial ${ }^{230}$ Th disequilibrium on young $\mathrm{U}-\mathrm{Pb}$ ages: the Makalu case, Himalaya. Earth and Planetary Science Letters, 67, pp. 191-204.

SCHARER, U., XU, R.-H., and ALLEGRE, C.J. 1986. U-(Th)-Pb systematics and ages of Himalayan leucogranites, South Tibet. Earth and Planetary Science Letters, 77, pp. 35-48.

STEIGER, R.H. and JAGER, E. 1977. Subcommission on geochronology: Convention on the decay constants in geo- and cosmochronology. Earth and Planetary Science Letters, 36, pp. 359-363.

THOMPSON, J.B., JR. and NORTON, S.A. 1968. Paleozoic regional metamorphism in New England and adjacent areas. In Studies of Appalachian geology: Northern and Maritime. Edited by E. Zen, W.S. White, J.B. Hadley, and J.B. Thompson Jr. Interscience Publishers, New York, pp. 319-327.

THOMPSON, P.J., ELBERT, D.C., and ROBINSON, P. 1987. Thrust nappes superimposed on fold nappes: a major component of early Acadian tectonics in the central Connecticut Valley region, New England. Geological Society of America, Abstracts with Programs, 19. p. 868.

TUCKER, R.D., RAHEIM, A., KROGH, T.E., and CORFU, F. 1986. Uranium-lead zircon and titanite ages from the northem portion of the Westem Gneiss Region, south-central Norway. Earth and Planetary Science Letters, 81, pp. 203-211.

WEST, D.P., JR., LUX, D.R., GUIDOTTI, C.V., HUSSEY, A.M., II. 1988a. ${ }^{40} \mathrm{Ar} /{ }^{\beta 9} \mathrm{Ar}$ mineral ages from the Casco Bay Group, southwestern Maine. Geological Society of America, Abstracts with Programs, 20, p. 7878.

WEST, D.P., JR., LUX, D.R., and HUSSEY, A.M., II. 1988b. ${ }^{\star A r} /{ }^{\star A}$ homblende ages from southwestem Maine: evidence for Late 
Paleozoic metamorphism. Maritime Sediments and Atlantic Geology, 24, pp. 225-239.

ZARTMAN, R.E., HURLEY, P.M., KRUEGER, H.W., and GILETTI, S.J. 1970. A Permian disturbance of K-Ar radiometric ages in New England: Its occurrence and cause. Geological Society of America, Bulletin 81, pp. 3359-3374.

ZARTMAN, R.E. and NAYLOR, R.S. 1984. Structural implications of some new radiometric ages of igneous rocks in southeastem New England. Geological Society of America, Bulletin 95, pp. 533-539.

ZARTMAN, R.E., HERMES, D.O., and PEASE, M.H., JR. 1988. Zircon crystallization ages, and subsequent isotopic disturbance events, in gneissic rocks of eastern Connecticut and western Rhode Island. American Journal of Science, 288, pp. 376-402.

ZEN, E., STEWART, D., and FYFFE, L.R. 1986. Paleozoic tectonostratigr aphic terranes and their boundaries in the mainland northem Appalachians. Geological Society of America, Abstracts with Programs, 18, p. 800.

\section{APPENDIX 1: ANALYTICAL PROCEDURES}

Monazite and sphenes were separated from the rocks using a Wifley table, heavy liquids, magnetic techniques and hand picking. On the average, $10 \mathrm{lbs}$ of schist and $100 \mathrm{lbs}$ of granite were crushed to acquire a suitable amount of monazite. Ten pounds of calc-silicate rock were crushed to acquire a suitable amount of sphene. Monazite and sphene were leached in $6 \mathrm{~N} \mathrm{HCl}$ and $\mathrm{HNO}_{3}$ acid to dissolve sulfides. The monazite was handpicked and panned in acetone to $99 \%$ purity. During this step all monazite with inclusions, most commonly opaques (sulfides?) and less commonly those with 'dirty', possibly inherited detrital, cores, were removed. The resulting separates consisted of translucent, round, yellow monazites with vitreous to waxy luster, ranging in size from 5 to 100 microns in diameter. Positive identification and purity of the separates were spot checked by immersion oil techniques and $\mathrm{X}$-ray diffraction.

After an acid wash in $7 \mathrm{~N} \mathrm{HNO}_{3}$, monazite was dissolved overnight, at least once and in some cases twice, in Teflon (Krogh, 1973) bombs at $205-210^{\circ} \mathrm{C}$ in $6.2 \mathrm{~N} \mathrm{HCl}$. Monazite was spiked with ${ }^{205} \mathrm{~Pb}^{23} \mathrm{U}$ before dissolution or aliquoted and then spiked with ${ }^{208} \mathrm{~Pb}-{ }^{235} \mathrm{U}$. $\mathrm{Pb}$ and $\mathrm{U}$ were eluted using $0.150 \mathrm{ml}$ exchange columns and $\mathrm{HCl}$ chemistry after Krogh (1973). The $\mathrm{Pb}$ blank in this procedure is $60-200 \mathrm{pg}$. Isotope ratios were measured on a MAT 261 multicollector mass spectrometer at the University of California, Santa Barbara. $\mathrm{Pb}$ was loaded on a single rhenium filament with $\mathrm{H}_{3} \mathrm{PO}_{4}-\mathrm{Si}$ gel; $\mathrm{U}$ was loaded with $\mathrm{HNO}_{3}$-graphite. Mass fractionation was monitored using NBS 981 and U500 standards, and amounted to $0.12 \%$ correction per mass unit. The error analysis used here follows Mattinson (1987), and depends on uncertainties in measured ratios, mass fractionation, identity of common $\mathrm{Pb}$, and the precision of the ${ }^{204} \mathrm{~Pb} /{ }^{200} \mathrm{~Pb}$ measurement. These uncertainties are much larger than any effect of initial unsupported ${ }^{230} \mathrm{Th}$ in the samples, which are in this case insignificant for the normal whole rock $\mathrm{Th} / \mathrm{U}$ values. Decay constants are from Steiger and Jager (1977). 